\title{
Taq I polymorphism of the vitamin D receptor and risk of severe diabetic retinopathy
}

\author{
M. J. Taverna ${ }^{1}$, A.Sola ${ }^{1}$, C. Guyot-Argenton ${ }^{2}$, N.Pacher ${ }^{1}$, F. Bruzzo ${ }^{1}$, G.Slama ${ }^{1}$, G. Reach ${ }^{1}$, J.-L.Selam ${ }^{1}$ \\ ${ }^{1}$ INSERM U341 and \\ ${ }^{2}$ Diabeto-Ophthalmology Unit, Department of Diabetology, Hôtel-Dieu, Hospital, Paris, France
}

\section{Abstract}

Aims/hypothesis. Vitamin D, a molecule with antiproliferative, antiangiogenic, antioxidant and immunosuppressive effects, could play a role in the pathogenesis of severe diabetic retinopathy. We examined whether Taq I polymorphism of the vitamin D receptor is involved in the development of severe diabetic retinopathy.

Methods. 200 unrelated C-peptide-negative French Type I diabetic patients were randomly selected (male:female, 103:97, age $44.4 \pm 12.4$ years, diabetes duration: $27.7 \pm 10.0$ years, BMI: $24.3 \pm 3.4 \mathrm{~kg} / \mathrm{m}^{2}$, $\mathrm{HbA}_{1 \mathrm{c}}: 8.6 \pm 1.3 \%$ ). The Taq I site was analysed by PCR followed by digestion with Taq I enzyme. Diabetic retinopathy was assessed by retinal angiography and classified as presence $(n=101)$ or absence $(n=99)$ of severe (preproliferative or proliferative) diabetic retinopathy.

Results. Frequency of wild-type genotype $T T$ was lower in patients with severe diabetic retinopathy $(n=27)$ when compared with control subjects $(n=42, \mathrm{OR}=0.5, p=0.028)$. Allele frequencies were not different between patients $(T: n=112$ and $t: n=90)$ and control subjects $(T: n=128$, and $t$ : $n=70, p=0.075)$. Global $\chi^{2}(d f=2): p=0.064$. In subjects with diabetes duration of more than 25 years, $T T$ was lower in severe diabetic retinopathy $(n=14)$ than control subjects $(n=18, \mathrm{OR}=0.3, p=0.01)$. Allele frequencies were different between patients $(T$ : $n=68$ and $t: n=66)$ and control subjects $(T: n=52$, $\mathrm{OR}=0.5$, and $t: n=26, \mathrm{OR}=1.9, p=0.034)$. Global $\chi^{2}(d f=2): p=0.024$. In subjects with $\mathrm{HbA}_{1 \mathrm{c}}$ over $9 \%, T t$ was higher in patients $(n=28)$ than control subjects $(n=15$, OR $=3.1, p=0.019)$. Allele frequencies were not different between patients $(T: n=52$ and $t: n=38)$ and control subjects $(T: n=57$, and $t$ : $n=29, p=0.31)$. Global $\chi^{2}(d f=2): p=0.035$.

Conclusion/interpretation. In French Type I (insulindependent) diabetic patients, we demonstrate an association between $T T$ form (VDR) and low risk for severe diabetic retinopathy, especially in patients with long duration, and between $T t$ variant and high risk for severe diabetic retinopathy in subjects with poor glycaemic control. [Diabetologia (2002) 45: 436-442]

Keywords Diabetic retinopathy, Taq I polymorphism, genetic, vitamin D receptor, diabetes.

\section{Received: 16 May 2001 and in revised form: 9 November 2001}

Corresponding author: J.-L. Selam, INSERM U341, HôtelDieu Hospital, Department of Diabetology, 1 place du Parvis de Notre-Dame, 75181 Paris Cedex 04, France, e-mail: jean-louis.selam@wanadoo.fr

Abbreviations: DR, Diabetic retinopathy; VDR, vitamin D receptor; VEGF, Vascular endothelial growth factor; IGF-1, insulin-like growth factor-1.
Neovascularization plays a role in determining the severity of diabetic retinopathy (DR) due to the effects of several angiogenic and growth factors, including vascular endothelial growth factor (VEGF), plateletderived growth factor (PDGF), basic fibroblast growth factor (bFGF) and insulin-like growth factor (IGF-1) [1].

Chronic hyperglycaemia induces non-severe diabetic retinopathy (DR) in most patients of long duration, but not severe DR in the majority of them, sug- 
gesting genetic factors play a role [2]. A sub-analysis of the Diabetes Control and Complications Trial (DCCT) showed a strong retinopathy transmission in families of patients with severe DR but not in those with non-severe DR [3]. Therefore, finding a genetic marker for this disease would be important in identifying patients who could benefit from preventive treatment.

It is well known that 1,25-dihydroxyvitamin D3 (calcitriol) is involved in the maintenance of mineral homeostasis. In addition, it has non-calciotropic effects, including antiproliferative, antiangiogenic, antioxidant and immunosupressive properties [4]. Recently, an inverse strong association between serum vitamin D concentrations and severity of DR was found [5], suggesting a protective role of active vitamin $\mathrm{D}$ forms for risk of severe DR.

The vitamin D receptor (VDR) is expressed in most cells of the retina including the endothelial cells, in animals and human beings [6-8]. Several polymorphisms of VDR have been associated with many conditions [9-18] including Type I (insulin-dependent) diabetes [11-14], Type II (non-insulin-dependent) diabetes mellitus [15], obesity [16] and insulin resistance [17].

Because of the relation between $t$ allele of Taq I polymorphism of the VDR and reduced steady state VDR mRNA [19], we hypothesized that Taq I polymorphism could be involved in the pathogenesis of severe DR through a reduction of the non-calciotropic effects of 1,25-dihydroxyvitamin D3.

To examine whether the Taq I polymorphism is involved in the development of severe DR in a Caucasian French cohort with Type I diabetes, a case-control study was carried out.

\section{Subjects and methods}

From a group of 1000 Type I diabetic patients who regularly attended the diabetes outpatient clinic at the Hôtel-Dieu Hospital of Paris, two groups of unrelated patients were recruited at random during 1999 and 2000. Patients were classified into the following categories: study group $(n=101)$ with severe DR including proliferative $(n=73)$ or preproliferative $(n=28) \mathrm{DR}$, and control group $(n=99)$ with absent $(n=32)$ or background $(n=67)$ DR. All patients enrolled in this study gave informed consent. The protocol was in agreement with the Declaration of Helsinki. All patients fulfilled the following criteria: Caucasian with Type I diabetes diagnosis before 35 years of age (WHO criteria), C-peptide-negative and medical follow-up by our medical staff for at least 2 years. To reduce a chance of diabetic patients being wrongly classified as having non-severe DR because of a short duration of diabetes, we selected only patients with a diabetes duration of more than 15 years. Stages of retinopathy were defined according to the EURODIAB IDDM Complications Study, by trained ophthalmologists, using fluorescein angiograms, except in cases where there was no DR (fundoscopy after pupillary dilatation). Our classification was as follows: control group, no DR (level 0) and background DR (levels 1 and 2); severe DR group, preproliferative (level 3) and proliferative DR (levels 4 and 5) [20]. DN was assessed by AER: normal AER ( < $30 \mathrm{mg} / 24 \mathrm{~h} ; n=114)$; microalbuminuria $(30-300 \mathrm{mg} / 24 \mathrm{~h}$; $n=40$ ); albuminuria ( $>300 \mathrm{mg} / 24 \mathrm{~h} ; n=46$ ). Urinary albumin concentration was determined by enzyme immunoassay from a 24-h urine collections. LDL-cholesterol concentrations were taken from medical records. High blood pressure (HBP) was defined by a systolic blood pressure greater than $139 \mathrm{mmHg}$ or a diastolic blood pressure greater than $89 \mathrm{mmHg}$ (measured with a sphygmomanometer after $5 \mathrm{~min}$ at rest) or by a pharmacological treatment for arterial hypertension. The patients underwent a physical examination and completed a standard questionnaire on personal medical history regarding diabetes diagnosis, treatment, occurrence of acute and chronic complications, family history of diabetes and its complications. Each individual provided a blood sample for biochemical analysis ( $\mathrm{HbA}_{1 \mathrm{C}}$ by HPLC method, Diamat, Bio-Rad, Hercules, Calif., USA and serum creatinine) and DNA extraction.

Genomic DNA was extracted from peripheral blood leukocytes of each patient using standard methods (Puregene, Gentra Systems, Minn., USA). The extracted DNA was stored at $4{ }^{\circ} \mathrm{C}$ until analysed. Genotypes were scored blindly. Ambiguous and homozygous samples were reanalysed. Polymerase chain reaction (PCR) of the DNA sequence flanking the Taq $I$ restriction site of the VDR gene was carried out using forward primer 5'-CCA AGA CTA CAA GTA CCG CG-3' and reverse primer 5'-TGA GGA GGG CTG CTG AGT-3' (Sigma-Genosys, Pampisford, Cambridgeshire, England). The PCR product was digested using restriction enzymes, Taq I (Life Technologies, Paisley, Scotland). Digestion reactions were set according to the manufacturers instructions. The digested product was fractionated using $2 \%$ agarose gel electrophoresis. Gels were stained with ethidium bromide and visualized under UV light and photographed. Absence or presence of T/C nucleotide substitution (ATT to ATC) leading to a synonymous change at codon 352 (isoleucine) in exon 9 was detected when Taq I restriction site was absent ( $T$ allele) or present ( $t$ allele), respectively [21].

The statistical difference in genotype distribution and allele frequencies among the groups and the subgroups (sorted by $\mathrm{HbA}_{1 \mathrm{c}}>9.0 \%$ and duration of diabetes $>25$ years) was assessed by $\chi^{2}$ (chi-square) analysis. When appropriate, the odds ratio and $95 \%-\mathrm{CI}$ estimating the relative risks of severe DR associated with Taq I polymorphism was calculated. Allele frequencies were used to calculate genotype frequencies according to the Hardy-Weinberg equilibrium. Comparisons between the clinical characteristics of the two groups were made by unpaired $t$ tests. A forward stepwise regression analysis was done to assess the influence of independent variables on severe DR (eg. sex, age, diabetes duration, $\mathrm{HbA}_{1 \mathrm{c}}$, hypertension, LDLcholesterol, albuminuria and Taq I polymorphism). A $p$ value of less than 0.05 was considered to be statistically significant.

\section{Results}

The two groups had a similar distribution of sex, age, BMI, smoking, LDL-cholesterol and microalbuminuria. Patients had a longer diabetes duration $(30.0 \pm 10.1$ vs $25.2 \pm 9.4$ years, $p<0.0001)$, higher $\mathrm{HbA}_{1 \mathrm{c}}$ concentrations $(8.9 \pm 1.4$ vs $8.3 \pm 1.1 \%$, $p<0.0001)$, higher serum creatinine concentration $(104.2 \pm 62.5$ vs $86.9 \pm 20 \mathrm{mg} / \mathrm{dl}, p<0.01)$ and, more frequent occurrence of arterial hypertension $(73.3 \mathrm{vs}$ $41 \%, p<0.02)$ and albuminuria (37.6 vs $8.1 \%$, 
Table 1. Genotype distribution and allele frequencies

\begin{tabular}{lccll}
\hline & Study group $(n=101)$ & Control group $(n=99)$ & OR $(95 \%-\mathrm{CI})$ & $p$ value (Yates corrected $p)$ \\
\hline Genotypes & & & & \\
$T T$ & $27(26.7)$ & $42(42.4)$ & $0.50(0.26-0.94)$ & $0.0196(0.028)$ \\
$T t$ & $58(57.4)$ & $44(44.4)$ & $1.69(0.93-3.07)$ & $0.066(0.090)$ \\
$t t$ & $16(15.8)$ & $13(13.1)$ & $1.25(0.53-2.95)$ & $0.58(0.73)$ \\
Alleles & & & & $0.68(0.45-1.04)$ \\
$T$ & $112(55.4)$ & $128(64.6)$ & $1.47(0.96-2.24)$ & $0.060(0.075)$ \\
$t$ & $90(44.6)$ & $70(35.4)$ & $0.060(0.075)$ \\
\hline
\end{tabular}

Data are expressed as $n$ (\%). TT, Tt and $t t$ are the wild-type, heterozygous and homozygous genotypes, respectively. Global $\chi^{2}$ $(d f=2)=5.47, p=0.064$

$p<0.0001)$, than control subjects. Normoalbuminuria was more frequent in control subjects than patients $(74.7$ vs $39.6 \%, p<0.001)$.

Genotypes in whole sample and in both study and control groups were in Hardy-Weinberg equilibrium ( $p=0.783, p=0.103$ and $p=0.377$, respectively). The genotype distribution was $T T 34.5 \%$, Tt $51 \%$ and $t t 14.5 \%$. The frequency of wild-type genotype $T T$ was lower in patients with severe DR $(n=27$, $26.7 \%$ ) when compared with control subjects $\left(n=42, \quad 42.4 \%, \quad \chi^{2}=5.45, \quad\right.$ OR $=0.5 \quad[95 \%-\mathrm{CI}=$ $0.26-0.94], p=0.019$, Yates corrected $p=0.028)$. The frequency of $T t$ was not different between patients $(n=58,57.4 \%)$ and control subjects $(n=44,44.4 \%$, $\chi^{2}=3.37, \mathrm{OR}=1.69[95 \%-\mathrm{CI}=0.93-3.07], p=0.066$, Yates corrected $p=0.090)$. The frequency of $t t$ variant was not different between patients $(n=16$, $15.8 \%)$ and control subjects $\left(n=13,13.1 \%, \chi^{2}=\right.$ $0.30, \quad \mathrm{OR}=1.25 \quad[95 \%-\mathrm{CI}=0.53-2.95], \quad p=0.58$, Yates corrected $p=0.73$ ). Allele frequencies showed a non significant difference between patients $(T$ allele: $n=112,55.4 \%$ and $t$ allele: $n=90,44.6 \%)$ and control subjects ( $T$ allele: $n=128,64.6 \%, \chi^{2}=3.53$, $\mathrm{OR}=0.68$ [95\%-CI $=0.45-1.04]$, and $t$ allele: $n=70$, $35.4 \%, \mathrm{OR}=1.47 \quad[95 \%-\mathrm{CI}=0.96-2.24], p=0.060$, Yates corrected $p=0.075)$. Global $\chi^{2}(d f=2)$ was not significant $\left(\chi^{2}=5.47, p=0.064\right)$. The genotype and alleles frequencies are summarized in Table 1.

When we analysed only those subjects who had had diabetes for more than 25 years (patients: $n=67$ and control subjects: $n=39$ ), the frequency of $T T$ was lower in patients with severe DR $(n=14,20.9 \%)$ when compared with control subjects $(n=18,46.2 \%$, $\chi^{2}=6.31, \mathrm{OR}=0.3[95 \%-\mathrm{CI}=0.11-0.79], p=0.006$, Yates corrected $p=0.01$ ). The frequency of $T t$ was not different between patients $(n=40,59.7 \%)$ and control subjects $\left(n=16,41.0 \%, \chi^{2}=2.74\right.$, OR $=2.1$ $[95 \%-\mathrm{CI}=0.88-5.15], \quad p=0.06, \quad$ Yates corrected $p=0.097)$. The frequency of $t t$ variant was not different between patients $(n=13,19.4 \%)$ and control subjects $\left(n=5,12.8 \%, \chi^{2}=0.36, \quad\right.$ OR $=1.6, \quad[95 \%$ $\mathrm{CI}=0.48-5.83], p=0.38$, Yates corrected $p=0.54$ ). Allele frequencies showed a difference between patients ( $T$ allele: $n=68,50.7 \%$ and $t$ allele: $n=66$, $49.3 \%$ ) and control subjects ( $T$ allele: $n=52,66.7 \%$, $\chi^{2}=4.46, \mathrm{OR}=0.5[95 \%-\mathrm{CI}=0.27-0.95]$, and $t$ allele: $n=26, \quad 33.3 \%, \quad$ OR $=1.9 \quad[95 \%-\mathrm{CI}=1.04-3.61]$, $p=0.02$, Yates corrected $p=0.034)$. Global $\chi^{2}$ $(d f=2)$ was significant $\left(\chi^{2}=7.47, p=0.024\right)$.

When we analysed only those subjects with $\mathrm{HbA}_{1 \mathrm{c}}$ concentration over $9.0 \%$ (patients: $n=45$ and control subjects: $n=43$ ), the frequency of $T T$ was not different between patients with severe DR $(n=12,26.7 \%)$ and control subjects $\left(n=21,48.8 \%, \chi^{2}=3.71, \mathrm{OR}=0.4\right.$ $[95 \%-\mathrm{CI}=0.14-1.01], \quad p=0.031, \quad$ Yates corrected $p=0.054)$. The frequency of $T t$ was higher in patients with severe DR $(n=28,62.2 \%)$ when compared with control subjects $\left(n=15,34.9 \%, \chi^{2}=5.53\right.$, OR $=3.1$ [95\%-CI $=1.18-8.09], \quad p=0.01$, Yates corrected $p=0.019)$. The frequency of $t t$ variant was not different between patients $(n=5,11.1 \%)$ and control subjects $\left(n=7,16.3 \%, \chi^{2}=0.16, \quad \mathrm{OR}=0.6 \quad[95 \%\right.$ $\mathrm{CI}=0.15-2.53], p=0.48$, Yates corrected $p=0.69$ ). Allele frequencies were not different between patients ( $T$ allele: $n=52,57.8 \%$ and $t$ allele: $n=38$, $42.2 \%)$ and control subjects ( $T$ allele: $n=57,66.3 \%$, $\chi^{2}=1.01, \mathrm{OR}=0.7[95 \%-\mathrm{CI}=0.36-1.34]$, and $t$ allele: $n=29, \quad 33.7 \%, \quad$ OR $=1.4 \quad[95 \%-\mathrm{CI}=0.74-2.77]$, $p=0.24$, Yates corrected $p=0.31)$. Global $\chi^{2}(d f=2)$ was significant $\left(\chi^{2}=6.67, p=0.035\right)$.

We compared clinical parameters between carriers ( $T t$ and $t t$ ) and non-carriers (TT). Only BMI was higher in carriers $(24.7 \pm 3.1 \mathrm{~kg} / \mathrm{m} 2)$ when compared with non-carriers $(23.1 \pm 3.2 \mathrm{~kg} / \mathrm{m} 2, p=0.03)$ at the study group. All data are summarized in Table 2.

The forward stepwise regression analysis confirmed that albuminuria $(F=16.5, p=0.00007), T T$ genotype $(F=5.05, p=0.026)$ and diabetes duration $(F=4.42, p=0.037)$, were the only significant independent variables for severe DR.

The distribution for $T T, T t$, and $t t$ genotypes and, $T$ and $t$ alleles was not different between normoalbuminuric $(n=41,36.0 \%, n=57,50.0 \%, n=16$, $14.0 \%, n=139,61.0 \%$ and $n=89,39.0 \%$, respectively), microalbuminuric $(n=16,40.0 \%, n=18$, $45.0 \%, n=6,15 \%, n=50,62.5 \%, n=30,37.5 \%$, respectively, NS) and albuminuric patients $(n=12$, $26.1 \%, n=27,58.7 \%, n=7,15.2 \%, n=51,55.4 \%$, $n=41,44.6 \%$, respectively, NS). Global $\chi^{2}(d f=4)$ was not significant $\left(\chi^{2}=2.24, p=0.69\right)$. 
Table 2. Comparison of clinical parameters according to Taq I genotypes

\begin{tabular}{|c|c|c|c|c|}
\hline & \multicolumn{2}{|c|}{$\begin{array}{l}\text { Study group }(n=101) \\
\text { (Proliferative, } n=73 ; \text { preproliferative DR, } n=28)\end{array}$} & \multicolumn{2}{|c|}{$\begin{array}{l}\text { Control group }(n=99) \\
\text { (Absent, } n=32 ; \text { background DR, } n=67)\end{array}$} \\
\hline & $T T$ vs $(n=27)$ & $T t(n=58)+t t(n=16)$ & $T T(n=42)$ vs & $T t(n=44)+t t(n=13)$ \\
\hline $\operatorname{Sex}(M / F)$ & $8 / 19$ & $37 / 37$ & $24 / 18$ & $34 / 23$ \\
\hline Age (years) & $46.3 \pm 12.0$ & $46.0 \pm 11.8$ & $43.0 \pm 12.7$ & $42.9 \pm 13.5$ \\
\hline Diabetes duration (years) & $29.5 \pm 11.3$ & $30.5 \pm 9.9$ & $25.5 \pm 8.5$ & $25.2 \pm 10.0$ \\
\hline Age of diagnostic (years) & $16.0 \pm 5.9$ & $15.7 \pm 7.5$ & $17.5 \pm 8.2$ & $17.8 \pm 8.1$ \\
\hline Weight $(\mathrm{kg})$ & $65.2 \pm 10.9$ & $69.5 \pm 11.7$ & $72.5 \pm 9.3$ & $70.8 \pm 12.4$ \\
\hline Height $(\mathrm{cm})$ & $167.6 \pm 8.7$ & $167.4 \pm 9.3$ & $171.2 \pm 8.5$ & $171.6 \pm 8.7$ \\
\hline BMI $\left(\mathrm{kg} / \mathrm{m}^{2}\right)$ & $23.1 \pm 3.2$ & $24.7 \pm 3.1 *$ & $24.7 \pm 3.2$ & $24.0 \pm 3.7$ \\
\hline $\mathrm{HbA}_{1 \mathrm{c}}(\%)$ & $9.29 \pm 1.44$ & $8.79 \pm 1.31$ & $8.08 \pm 1.19$ & $8.51 \pm 1.19$ \\
\hline LDL cholesterol (mg/dl) & $1.23 \pm 0.59$ & $1.27 \pm 0.41$ & $1.26 \pm 0.43$ & $1.19 \pm 0.31$ \\
\hline Hypertension $(n, \%)$ & $20(74.1)$ & $54(73.0)$ & $18(42.9)$ & $23(40.4)$ \\
\hline Systolic pressure (mmHg) & $134.5 \pm 18.6$ & $140.2 \pm 21.1$ & $137.1 \pm 16.9$ & $133.9 \pm 16.8$ \\
\hline Diastolic pressure $(\mathrm{mmHg})$ & $73.2 \pm 9.6$ & $77.9 \pm 11.2$ & $75.6 \pm 10.1$ & $74.7 \pm 8.4$ \\
\hline Smoking $(n, \%)$ & $7(26.0)$ & $28(37.8)$ & $18(42.9)$ & $21(36.8)$ \\
\hline Serum creatinine $(\mathrm{mg} / \mathrm{dl})$ & $92.6 \pm 32.0$ & $108.7 \pm 70.8$ & $84.6 \pm 17.6$ & $89.6 \pm 22.0$ \\
\hline Normoalbuminuria $(n, \%)$ & $11(40.7)$ & $29(39.2)$ & $30(71.4)$ & $44(77.2)$ \\
\hline Microalbuminuria $(n, \%)$ & $6(22.2)$ & $17(23.0)$ & $10(23.8)$ & 7 (12.3) \\
\hline Albuminuria $(n, \%)$ & $10(37.0)$ & $28(37.8)$ & $2(4.8)$ & $6(10.5)$ \\
\hline
\end{tabular}

$* p=0.03$ between carriers and non-carriers from the study group. The other comparisons intragroup are NS

\section{Discussion}

We have shown that $T T$ variant of Taq I polymorphism of VDR is associated with non-severe DR (absent or background DR) in a French Caucasian cohort with Type I diabetes, especially in patients who had diabetes longer than 25 years, and also that the $T t$ variant is associated with high risk of severe DR in patients with $\mathrm{HbA}_{1 \mathrm{c}}$ concentrations of more than $9.0 \%$. Although the frequency of $T$ allele showed no statistical difference at the whole population, it was slightly lower in retinopathic patients $(55.4 \%)$ when compared with control subjects $(64.6 \%$, $p=0.075)$, a finding reinforced by a reduced odds ratio and the narrow bounds of the $95 \%-\mathrm{CI}(\mathrm{OR}=0.7$ $[95 \%-\mathrm{CI}=0.45-1.04])$. It is not surprising that interactions between $T t$ genotype and $\mathrm{HbA}_{1 \mathrm{c}}$ of more than $9.0 \%$ and, especially, between $T T$ genotype and diabetes duration of more than 25 years amplified the effect of Taq I polymorphism found at whole population. Most case-control studies have found that analysis of the association between VDR polymorphisms, including Taq I site, and other different conditions (eg. osteoporosis, cancer) requires the inclusion of other potentially relevant variables (eg. calcium intake, ageing) [9, 21, 22]. Our study of these interactions was based on the fact that a long duration of diabetes and poor glycaemic control are involved in DR [23]; a long duration of diabetes has been significantly correlated with low serum vitamin D concentration $(p<0.05)$ in Caucasian individuals with Type II diabetes [5], as has poor glycaemic control $[24,25]$. In addition, hyperglycaemia has been associated with reduced vitamin D effects on bone cells $[26,27]$ and low VDR expression in intestinal and renal cells [28].
Although diabetes duration, $\mathrm{HbA}_{1 \mathrm{c}}$ concentration, hypertension and albuminuria were different between the study and control groups $(p<0.0001$, $p<0.001, p<0.02$ and $p<0.001$, respectively), forward stepwise regression showed that $T T$ genotype effect on DR risk was not affected by those variables. Updated $\mathrm{HbA} l c$ concentration was not significant $(p=0.053)$. Unfortunately, baseline $\mathrm{HbA}_{1 \mathrm{c}}$ concentrations, a better parameter of chronic glycaemic exposure, [23], were not available for analysis. Furthermore, non-glycaemic factors could be important in the progression of diabetic complications [3, 23]. Even though our study did not include non-diabetic control subjects, the distribution of Taq I polymorphism among our cohort was similar to that observed in other French cohorts [16, 29], thus excluding a selection bias.

We hypothesized that antiproliferative, antiangiogenic, antioxidant and immunosuppressive properties of 1,25-dihydroxyvitamin D3 protect against severe $\mathrm{DR}$, and this effect must requires a normal function of VDR. Recently, a strong inverse association was found between serum vitamin $\mathrm{D}$ concentration and severity of DR [5], suggesting a protective role of active vitamin D for risk of severe DR. Treatment with calcitriol inhibits angiogenesis and reduces the size of tumors in transgenic murine retinoblastoma, in a dose-dependent manner, an effect well recognized in other tumours [30] including in human cells of retinoblastoma [8]. Moreover, it was found that topical administration of calcitriol can strongly reduce corneal neovascularization inhibiting leucocyte migration, and could also inhibit IL-1 alpha, IL-1 beta and IL-8 production by human corneal cells in vitro [31]. This could be partly because of its capacity to downregulate nuclear factor-kappa B [32]. Recently, one report 
showed that calcitriol could inhibit VEGF [33] although other studies found the opposite effect [34]. On the other hand, calcitriol strongly represses the IGF-1 pathway because of its ability to stimulate insulin-like growth factor binding protein-3 secretion [35]. Finally, functional genetic studies support our hypothesis. For example, investigators found in three different types of human cells, that steady state concentrations of VDR mRNA with $T$ allele were $30 \%$ higher than $t$ allele [19]. Moreover, in gene constructs containing the 3'untranslated region (3'UTR) from individuals homozygous for baT haplotype, activity of cells transfected was found to be increased 1.5fold to fivefold when compared with 3'UTR from individuals homozygous for $B A t$ haplotype, an effect of the increase VDR mRNA stability [36]. However, previous studies had suggested the opposite effect $[37,38]$.

Although most of the above-mentioned effects have been shown in a dose-dependent manner, and especially at pharmacological concentrations, some reports have found, after administration of low calcitriol doses, and in different types of animals and human cells, significant growth cell inhibition, antioxidant activity and immunosuppressive effects, despite physiologic concentrations of calcitriol [39-43].

Because a risk of DR has been associated with insulin resistance [44] and low beta-cell function [45, 46], active vitamin D could induce retinal protection indirectly by inducing beta-cell protection [47], insulin secretion [48-50] and insulin sensitivity [49-51]. Interestingly, at least one report associated the $b$ allele of Bsm I, which shows strong linkage disequilibrium with $T$ allele of $T a q$ I site, with significantly lower serum calcitriol concentrations than control subjects [52], although other studies found the opposite effect [21]. In addition, VDR genotype combination $B A t$ confers high risk for Type I diabetes in German people [11].

We cannot exclude the possibility that the $T T$ variant of the Taq I site is a marker of a nearby functional polymorphism within the VDR gene or a nearby gene. Interestingly, the G-protein beta 3 subunit gene (GNB3) is located very near to the VDR locus (12q12-q13 and 12q12-q14, respectively), and this family of proteins has been associated with many regulatory functions including cell growth and angiogenesis [53]. One report has showed an association between diabetic nephropathy and a genetic variant in the G-protein beta 3 subunit, C825T polymorphism [54]. However, no association between the latter and DR exists, and, the majority of reports on diabetic nephropathy have not found any association [55].

Because the functional effects of Taq I genotypes could be tissue-specific as with other VDR polymorphisms [21,22], and because the physiopathology of DR is quite different from that of diabetic nephropathy it not surprising that there is no association be- tween Taq I polymorphism and the latter. Polymorphisms clearly involved in DR could have no role to play in diabetic nephropathy (eg. microsatellite 5' of aldose reductase), and vice versa (eg. polymorphism I/D of the angiotensin- 1 converting enzyme) [56, 57]. However, the aim of our study was not to investigate diabetic nephropathy and the existence of many different VDR polymorphisms which we did not study, means that there could be an association between VDR polymorphisms and this complication. Recently, a small observational study in Italian subjects found no transmission of $B B$ genotype - wild-type form of the BsmI polymorphism of VDR - among 15 diabetic individuals, from 86 uremic patients [58].

In conclusion, we have shown an association between the $T T$ variant of the Taq I polymorphism of VDR and low risk for severe DR in French Type I diabetic patients, especially in patients who had diabetes for a long time, and between the $T t$ variant and a high risk of severe DR in patients with poor glycaemic control.

Acknowledgements. This work was funded by the French National Institute of Health and Medical Research (Institut National de la Santé et de la Recherche Médicale de France) (INSERM). M.J. Taverna received a scholarship grant from the Foundation of the Clinical Hospital of Buenos Aires University (Fundación del Hospital de Clinicas de Buenos Aires) (3/ 1999-5/1999) and Foundation Cross of the South of Buenos Aires (Fundación Cruz del Sur de Buenos Aires) (3/1999-5/ 1999). We thank Prof. P. Froguel for his initial advice and, Dr. Viriot-Leroy, Dr. Hadj-Allal and Dr. Arhab for having performed the ophthalmological examinations.

\section{References}

1. Miller JW, Adamis AP, Aiello LP (1997) Vascular endothelial growth factor in ocular neovascularization and proliferative diabetic retinoapthy. Diabetes Metab Rev 13: 37-50

2. Klein R, Klein BE, Moss SE, Davis MD, DeMets DL (1984) The Wisconsin epidemiologic study of diabetic retinopathy. II. Prevalence and risk of diabetic retinopathy when age at diagnosis is less than 30 years. Arch Ophthalmol 102: 520-526

3. The Diabetes Control and Complications Trial Research Group (1997) Clustering of long-term complications in families with diabetes in the Diabetes Control and Complications Trial. Diabetes 46: 1829-1839

4. Reichel H, Koeffler H, Norman AW (1989) The role of the vitamin $\mathrm{D}$ endocrine system in health and disease. $\mathrm{N}$ Eng $\mathrm{J}$ Med 320: 980-991

5. Aksoy H, Akcay F, Kurtul N et al. (2000) Serum 1,25 dihydroxy vitamin D $(1,25(\mathrm{OH}) 2 \mathrm{D} 3), 25$ hydroxy vitamin D $(25(\mathrm{OH}) \mathrm{D})$ and parathormone levels in diabetic retinopathy. Clin Biochem 33: 47-51

6. Schreiner DS, Jande SS, Lawson DEM (1985) Target cells of vitamin D in the vertebrate retina. Acta Anat (Basel) 121: $153-162$

7. Johnson JA, Grande JP, Roche PC, Campbell RJ, Kumar R (1995) Immuno-localization of the calcitriol receptor, calbindin-D28 $\mathrm{k}$ and the plasma membrane calcium pump in the human eye. Curr Eye Res 14: 101-108 
8. Saulenas AM, Cohen SM, Key LL, Winter C, Albert DM (1988) Vitamin D and retinoblastoma. The presence of receptors and inhibition of growth in vitro. Arch Ophthalmol 106: 533-535

9. Gong G, Stern HS, Cheng S-C et al. (1999) The association of bone mineral density with vitamin $\mathrm{D}$ receptor gene polymorphisms. Osteoporos Int 9: 55-64

10. Ingles SA, Coetzee GA, Ross RK et al. (1998) Association of prostate cancer with vitamin $\mathrm{D}$ receptor haplotypes in African-Americans. Cancer Res 58: 1620-1623

11. Pani MA, Knapp M, Donner H et al. (2000) Vitamin D receptor allele combinations influence genetic susceptibility to type 1 diabetes in Germans. Diabetes 49: 504-507

12. McDermott MF, Ramachandran A, Ogunkolade BW et al. (1997) Allelic variation in the vitamin D receptor influences susceptibility to IDDM in Indian Asians. Diabetologia 40: 971-975

13. Chang TJ, Lei HH, Yeh JI et al. (2000) Vitamin D receptor gene polymorphisms influence susceptibility to type 1 diabetes mellitus in the Taiwanese population. Clin Endocrinol (Oxf) 52: 575-580

14. Hitman GA, Mannan N, McDermott MF et al. (1998) Vitamin $\mathrm{D}$ receptor gene polymorphisms influence insulin secretion in Bangladeshi Asians. Diabetes 47: 688-690

15. Speer G, Cseh K, Winkler G et al. (2001) Vitamin D and estrogen receptor gene polymorphisms in type 2 diabetes mellitus and in android type obesity. Eur J Endocrinol 144: 385-389

16. Ye WZ, Reis AF, Dubois-Laforgue D, Bellanne-Chantelot C, Timsit J, Velho G (2001) Vitamin D receptor gene polymorphisms are associated with obesity in type 2 diabetic subjects with early age of onset. Eur J Endocrinol 145: 181-186

17. Chiu KC, Chuang LM, Yoon C (2001) The vitamin D receptor polymorphism in the translation initiation codon is a risk factor for insulin resistance in glucose tolerant Caucasians. BMC Med Genet 2: 2-8

18. Van Schooten FJ, Hirvonen A, Maas L et al. (1998) Putative susceptibility markers of coronary artery disease: association between VDR genotype, smoking, and aromatic DNA adduct levels in human right atrial tissue. FASEB J 12: $1409-1416$

19. Verbeek W, Gombart AF, Shiohara M, Campbell M, Koeffler HP (1997) Vitamin D receptor: no evidence for allelespecific mRNA stability in cells which are heterozygous for the TaqI restriction enzyme polymorphism. Biochem Biophys Res Commun 238: 77-80

20. Aldington SJ, Kohner EM, Meuer S, Klein R, Sjolie AK (1995) Methodology for retinal photography and assessment of diabetic retinopathy: the EURODIAB IDDM Complications Study. Diabetologia 38: 437-444

21. Zmuda J, Cauley JA, Ferrell RE (2000) Vitamin D receptor gene variants and osteoporosis. Epidemiol Rev 22: 203-217

22. Farrow S (1994) Allelic variation and the vitamin D receptor. Lancet 343: 1242

23. The Diabetes Control and Complications Trial Research Group (1995) The relationship of glycaemic exposure (HbA1 c) to the risk of development and progression of retinopathy in the Diabetes Control and Complications Trial. Diabetes 44 : 968-983

24. Nyomba BL, Bouillon R, Lissens W, Van Baelen H, De Moor P (1985) 1,25-dihydroxyvitamin D and vitamin Dbinding protein are both decreased in streptozotocin-diabetic rats. Endocrinology 116: 2483-2488

25. Nyomba BL, Bouillon R, Bidingija M, Kandjingu K, De Moor P (1986) Vitamin D metabolites and their binding protein in adult diabetic patients. Diabetes 35: 911-915
26. Patel SR, Xu Y, Koenig RJ, Hsu CH (1997) Effect of glucose on the function of the calcitriol receptor and vitamin D metabolism. Kidney Int 52: 79-86

27. Inaba M, Terada M, Koyama $H$ et al. (1995) Influence of high glucose on 1,25-dihydroxyvitamin D3-induced effect on human osteoblast-like MG-63 cells. J Bone Miner Res 10: $1050-1056$

28. Ishida H, Cunningham NS, Henry HL, Norman AW (1988) The number of 1,25-dihydroxyvitamin D3 receptors is decreased in both intestine and kidney of genetically diabetic $\mathrm{db} / \mathrm{db}$ mice. Endocrinology 122: 2436-2443

29. Correa-Cerro L, Berthon P, Haussler J et al. (1999) Vitamin D receptor polymorphisms as markers in prostate cancer. Hum Genet 105: 281-287

30. Shokravi MT, Marcus DM, Alroy J, Egan K, Saornil MA, Albert DM (1995) Vitamin D inhibits angiogenesis in transgenic murine retinoblastoma. Invest Ophthalmol Vis Sci 36: $83-87$

31. Suzuki T, Sano Y, Kinoshita S (2000) Effects of 1alpha,25dihydroxyvitamin D3 on Langerhans cell migration and corneal neovascularization in mice. Invest Ophthalmol Vis Sci 41: 154-158

32. Harant H, Andrew PJ, Reddy GS, Foglar E, Lindley IJ (1997) 1alpha,25-dihydroxyvitamin D3 and a variety of its natural metabolites transcriptionally repress nuclear-factor-kappaB-mediated interleukin-8 gene expression. Eur J Biochem 250: 63-71

33. Mantell DJ, Owens PE, Bundred N, Mawer EB, Canfield AE (2000) 1 alpha,25-dihydroxyvitamin $\mathrm{D}(3)$ inhibits angiogenesis in vitro and in vivo. Circ Res 87: 214-220

34. Schlaeppi JM, Gutzwiller S, Finkenzeller G, Fournier B (1997) 1,25-Dihydroxyvitamin D3 induces the expression of vascular endothelial growth factor in osteoblastic cells. Endocr Res 23: 213-229

35. Sprenger CC, Peterson A, Lance R, Ware JL, Drivdahl RH, Plymate SR (2001) Regulation of proliferation of prostate epithelial cells by 1,25-dihydroxyvitamin D3 is accompanied by an increase in insulin-like growth factor binding protein-3. J Endocrinol 170: 609-618

36. Beaumont M, Bennett DA, White DA et al. (1998) Allelic differences in the 3'untra,slated region of the vitamin D receptor gene affect mRNA levels in bone cells. Osteoporos Int 8 [suppl 3]: 37 (Abstract)

37. Morrison NA, Qi JC, Tokita A et al. (1994) Prediction of bone density from vitamin D receptor alleles. Nature 367: 284-287

38. Carling T (2001) Molecular pathology of parathyroid tumors. Trends Endocrinol Metab 12: 53-58

39. Chatterjee M (2001) Vitamin D and genomic stability. Mutat Res 475: 69-87

40. Schwartz GG, Wang MH, Zang M, Singh RK, Siegal GP (1997) 1 alpha,25-Dihydroxyvitamin D (calcitriol) inhibits the invasiveness of human prostate cancer cells. Cancer Epidemiol Biomarkers Prev 6: 727-732

41. Skowronski RJ, Peehl DM, Feldman D (1993) Vitamin D and prostate cancer: 1,25 dihydroxyvitamin D3 receptors and actions in human prostate cancer cell lines. Endocrinology 132: 1952-1960

42. Boyan BD, Schwartz Z, Carnes DL Jr et al. (1988) The effects of vitamin D metabolites on the plasma and matrix vesicle membranes of growth and resting cartilage cells in vitro. Endocrinology 122: 2851-2860

43. Gross M, Kost SB, Ennis B, Stumpf W, Kumar R (1986) Effect of 1,25-dihydroxyvitamin D3 on mouse mammary tumor (GR) cells: evidence for receptors, cellular uptake, inhibition of growth and alteration in morphology at physiologic concentrations of hormone. J Bone Miner Res 1: 457-467 
44. Chaturvedi N, Sjoelie AK, Porta M et al. (2001) Markers of insulin resistance are strong risk factors for retinopathy incidence in type 1 diabetes. Diabetes Care 24: 284-289

45. Nakanishi K, Kobayashi T, Inoko H, Tsuji K, Murase T, Kosaka K (1995) Residual beta-cell function and HLAA24 in IDDM. Markers of glycaemic control and subsequent development of diabetic retinopathy. Diabetes 44: $1334-1339$

46. Suzuki K, Watanabe K, Motegi T, Kajinuma H (1989) High prevalence of proliferative retinopathy in diabetic patients with low pancreatic B-cell capacity. Diabetes Res Clin Pract 6: 45-52

47. Inaba M, Nishizawa Y, Song K et al. (1992) Partial protection of 1 alpha-hydroxyvitamin D3 against the development of diabetes induced by multiple low-dose streptozotocin injection in CD-1 mice. Metabolism 41: 631-635

48. Ayesha I, Bala TS, Reddy CV, Raghuramulu N (2001) Vitamin $D$ deficiency reduces insulin secretion and turnouver in rats. Diabetes Nutr Metab 14: 78-84

49. Kumar S, Davies M, Zakaria Y et al. (1994) Improvement in glucose tolerance and beta-cell function in a patient with vitamin $\mathrm{D}$ deficiency during treatment with vitamin D. Postgrad Med J 70: 440-443

50. Cade C, Norman AW (1986) Vitamin D3 improves impaired glucose tolerance and insulin secretion in the vitamin D-deficient rat in vivo. Endocrinology 119: 84-90

51. Turk S, Yeksan M, Tamer N, Gurbilek M, Erdogan Y, Erkul I (1992) Effect of 1,25 (OH)2D3 treatment on glucose intolerance in uraemia. Nephrol Dial Transplant 7: $1207-1212$
52. Chudek J, Karkoszka H, Schmidt-Gayk H, Ritz E, Kokot F (2000) Plasma parathyroid hormone, phosphatemia and vitamin D receptor genotype: are they interrelated? J Nephrol 13: 54-58

53. Richard DE, Vouret-Craviari V, Pouyssegur J (1991) Angiogenesis and G-protein-coupled receptors: signals that bridge the gap. Oncogene 26: 1556-1562

54. Bluthner M, Schmidt S, Siffert W, Knigge H, Nawroth P, Ritz E (1999) Increased frequency of G-protein beta-3 subunit $825 \mathrm{~T}$ allele in dialyzed patients with type 2 diabetes. Kidney Int 55: 1247-1250

55. Schcherbak NS, Schwartz EI (2001) The C825T polymorphism in the G-protein beta3 subunit gene and diabetic complications in IDDM patients. J Hum Genet 46: 188-191

56. Ichikawa F, Yamada K, Ishiyama-Shigemoto S, Yuan X, Nonaka K (1999) Association of an (A-C)n dinucleotide repeat polymorphic marker at the 5'-region of the aldose reductase gene with retinopathy but not with nephropathy or neuropathy in Japanese patients with Type 2 diabetes mellitus. Diabet Med 16: 744-748

57. Fujisawa T, Ikegami H, Kawaguchi Y et al. (1998) Metaanalysis of association of insertion/deletion polymorphism of angiotensin I-converting enzyme gene with diabetic nephropathy and retinopathy. Diabetologia 41: 47-53

58. Aterini S, Pacini S, Amato M, Ruggiero M (2000) Vitamin $\mathrm{D}$ receptor gene polymorphism and diabetes mellitus prevalence in hemodialysis patients. Nephron 84: 186 